\title{
RANCANGAN APLIKASI ORGANISASI PENCAK SILAT PERSAUDARAAN SETIA HATI TERATE RAYON BEKASI
}

\author{
Ismoyo Bayu Aji ${ }^{1}$, Andi Prastomo ${ }^{2}$, Septian Wulandari ${ }^{3}$ \\ Program Studi Teknik Informatika, Fakultas Teknik dan Ilmu Komputer, \\ Universitas Indraprasta PGRI \\ Jalan Raya Tengah No. 80, Kelurahan Gedong, Pasar Rebo, Jakarta Timur \\ meymoy95@gmail.com ${ }^{1}$, andi_prastomo@ymail.com ${ }^{2}$, septian.pmb09@ rocketmail.com ${ }^{3}$
}

\begin{abstract}
Abstrak
Persaudaraan Setia Hati Terate (PSHT) Rayon Bekasi merupakan salah satu organisasi pencak silat, dimana jumlah anggotanya mengalami peningkatan setiap tahunnya, baik dari pelatih maupun siswa. Oleh karena itu, membuat sekretaris dan bendahara mengalami kesulitan untuk mengelola data-data organisasi. Dikarenakan proses pendataan organisasi yang masih manual, membuat pencarian data dan pembuatan laporan organisasi membutuhkan waktu yang cukup lama. Penelitian ini dilakukan menggunakan metode grounded research yaitu prosedur pada fakta serta analisa perbandingan yang bertujuan untuk membuktikan teori, mengembangkan konsep-konsep, dan menganalisa data berjalan pada waktu yang bersamaan. Tujuan penelitian ini adalah untuk menganalisis permasalahan yang ada di Organisasi Pencak Silat Persaudaraan Setia Hati Terate Rayon Bekasi, dan membuat aplikasi organisasi yang mempermudahkan pengurus dalam hal pengelolaan data-data organisasi yang memerlukan kecepatan, dan ketepatan. Dalam membangun aplikasi ini menggunakan bahasa pemrograman Java, dan MySQL sebagai database penyimpanan. Adapun hasil penelitian ini untuk mempermudahkan pihak pengurus organisasi dalam hal pendataan, dan pencarian data siswa, data pelatih, dan data keuangan organisasi.
\end{abstract}

Kata Kunci : Aplikasi, Organisasi, PSHT, Java, MySQL

\begin{abstract}
Persaudaraan Setia Hati Terate (PSHT) Rayon Bekasi is one of martial arts pencak silat organizations, where the number of members has increased every year, both from the trainers, and the students. In this case both the secretary, and the treasurer can get a call to manage the organizations data. Due to the ongoing process off the organization is still manual, so in data search and creating a organization report takes a considerable time. This research using the grounded research method, a procedure in fact and comparative analysis intended to prove the theory, to develop concepts, and to analyze the data running at the same time. This purpose of the research is to analyze the problems that exist in Organizational Pencak Silat Persaudaraan Setia Hati Terate Rayon Bekasi, and make organizational applications that facilitate management in terms of managing organizational data that require speed, and accuracy. In building this application using the Java, and MySQL programming languages as the storage database. As for the results of this study to facilitate the management of the organizations in terms of data collection, and search students data, students coach data, and organizational financial data.
\end{abstract}

Keywords : Application, Organization, PSHT, Java, MySQL

\section{PENDAHULUAN}

Organisasi merupakan suatu kesatuan yang terbentuk oleh beberapa orang yang memiliki sedikit atau semua kesamaan atau latar belakang, identitas, harapan, dan berbagai hal lainnya untuk mencapai tujuan secara bersama sama, sehingga dibutuhkan persamaan persepsi anggota, pandangan, serta visi, dan misi untuk mencapai tujuan yang telah ditentukan bersama-sama (Duha 2018). Organisasi memiliki berbagai macam jenis antara lain organisasi budaya, kemanusiaan, dan kemasyarakatan. Salah satu organisasi yang mengembangkan budaya adalah pencak silat. Pencak silat merupakan seni gerak yang terlahir dari budaya manusia Indonesia untuk membela, mempertahankan, eksistensi, dan integritasnya terhadap alam sekitarnya. Pencak silat dapat dikategorikan sabagai warisan leluhur yang harus dijaga eksistensinya agar tidak punah tergerus zaman (Gristyutawati 2012). Salah satu aliran pencak silat adalah Persaudaraan Setia Hati Terate (PSHT). PSHT memiliki sub rayon salah satunya PSHT Rayon Bekasi, perkembangan organisasi ini setiap tahunnya mengalami peningkatan dalam hal jumlah anggota, baik dari pelatih dan siswa. Dibalik peningkatan jumlah anggota, terdapat permasalahan yang dialami antara lain, pengelolaan 
data organisasi belum terkomputerisasi, sehingga dalam hal pencarian, dan merivisi data membutuhkan waktu yang lama. Berdasarkan permasalahan diatas peneliti tertarik membangun "Rancangan Aplikasi Organisasi Pencak Silat Persaudaraan Setia Hati Terate Rayon Bekasi Berbasis Java". Tujuan penelitian ini adalah untuk menganalisis permasalahan yang ada di organisasi dan membangun aplikasi Organisasi Pencak Silat Persaudaraan Setia Hati Terate Rayon Bekasi. Aplikasi merupakan suatu program siap pakai yang direka untuk melaksanakan suatu fungsi bagi pengguna, dapat mengatasi permasalahan yang dihadapi pengguna dan membantu pekerjaan pengguna lebih efektif dan efisien.

\section{PENELITIAN YANG RELEVAN}

Dalam rangka mendapatkan penelitian yang baik, selain melakukan penelitian langsung peneliti juga melakukan kajian perpustakaan dari hasil penelitian yang telah dilakukan. Berikut ini hasil penelitian yang menjadi acuan: Wahyu Putra, dkk. STIKOM Dinamika Bangsa Jambi tahun 2019 dengan judul "Perancangan Aplikasi Organisasi Mahasiswa Center Berbasis Android (Studi Kasus : STIKOM Dinamika Bangsa Jamb)". Hasil penelitian yang dilakukan peneliti untuk membangun sistem pendaftaran anggota organisasi mahasiswa.(Ilmiah et al. 2019). Vikri Zulfi Ferdiansyah, Universitas Muhammadiyah Malang tahun 2017 dengan judul "Aplikasi Pembelajaran Interaktif Pencak Silat Persaudaraan Setia Hati Terate Berbasis Mobile". Hasil penelitian yang dilakukan peneliti untuk mengenalkan kepada masyarakat tentang pencak silat melalui aplikasi mobile (Ferdiansyah 2017). Nadia Septa Witriani, Politeknik Negeri Bandung tahun 2017, dengan judul "Aplikasi Pengelolaan Data Organisasi Mahasiswa". Hasil penelitian yang dilakukan oleh peneliti untuk membantu anggota organisasi dalam melakukan pengelolaan data yang lebih baik (Witirani 2017). Penelitian yang dilakukan peneliti, terfokus pada pendataan data siswa, data pelatih, data inventaris, dan data keuangan organisasi yang terdapat di Organisasi Pencak Silat Persaudaraan Setia Hati Terate Rayon Bekasi.

\section{METODE PENELITIAN}

Metode penelitian merupakan suatu prosedur untuk mengumpulkan dan menganalisa suatu data, berdasarkan prosedur tersebut peneliti dapat mengolah data dan menjadikannya menjadi suatu informasi (Suyoto 2015). Metode penelitian yang digunakan oleh peneliti adalah metode grounded research yaitu prosedur pada fakta serta analisa perbandingan yang bertujuan untuk membuktikan teori, mengembangkan konsep-konsep, dan menganalisa data berjalan pada waktu yang bersamaan atau berdasarkan asas verifikasi teori (Nissa et al. 2020). Guna mengumpulkan data dan informasi yang dibutuhkan untuk menunjang hasil penelitian, peneliti menggunakan metode pengumpulan data antara lain: studi lapangan dan studi kepustakaan. Studi lapangan dilakukan peneliti untuk melihat secara langsung penerapan pendataan dan pengelolaan data yang ada di Organisasi Pencak Silat PSHT Rayon Bekasi. Studi lapangan yang dilakukan peneliti adalah observasi dan wawancara. Hasil dari studi lapangan untuk mendapatkan data-data penunjang penelitian dan untuk mengetahui permasalahan yang ada di PSHT Rayon Bekasi. Studi kepustakaan digunakan peneliti untuk mengumpulkan data dan informasi yang berasal dari kutipan-kutipan buku, jurnal, penelitian, dan sumber-sumber referensi lainnya. Dari bahan-bahan tersebut dapat diambil sebuah teori yang menjadi dasar dari penelitian dan digunakan untuk memecahkan permasalahan yang ada.

Langkah-langkah pengembangan sistem yang dilakukan peneliti antara lain: analisa kebutuhan, pada proses ini peneliti menentukan user dari aplikasi, dan menentukan kebutuhan dari masingmasing user. Studi kepustakaan, pada proses ini peneliti menambah referensi untuk keberhasilan penelitian ini. Perancangan sistem, pada proses ini peneliti merancang tampilan antarmuka (user interface) dari aplikasi. Pengembangan dan validasi sistem, pada proses ini peneliti membuat sistem yang mudah digunakan oleh pengguna (user friendly) dan membuat sistem yang dapat menunjang pendataan data-data organisasi. Implementasi, evaluasi, dan pengujian sistem, pada proses ini peneliti menerapkan aplikasi yang telah dibuat dan melakukan tahapan-tahapan pengujian untuk mengecek adanya kesalahan-kesalahan atau bug dari aplikasi. 


\section{HASIL DAN PEMBAHASAN}

Analisa Permasalahan

Pengelolaan data-data Organisasi Pencak Silat PSHT Rayon Bekasi belum memiliki sistem yang terkomputerisasi, penyimpanan data-data organisasi masih dalam bentuk media penyimpanan kertas. Dimana pengurus mengalami kendala dalam hal pencarian data, merevisi data, dan pembuatan laporan yang membutuhkan waktu lama.

\section{Alternatif Penyelesaian Masalah}

Berdasarkan analisa permasalahan yang dihadapi Organisasi Pencak Silat PSHT Rayon Bekasi, peneliti memberikan solusi alternatif pembuatan sistem yang dapat mengatasi permasalahan tersebut, pembuatan sistem yang dapat membantu pengurus organisasi dalam hal mencari data, merevisi data, dan membuat laporan dengan cepat dan tepat.

Adapun aturan yang diusulkan pada Rancangan Aplikasi Organisasi Pencak Silat Persaudaraan Setia Hati Terate Rayon Bekasi sebagai berikut:

1. Penginputan Data Siswa

Prosedur ini dilakukan oleh admin atau sekretaris sebagai bagian dari struktural organisasi yang bertugas mengelola data siswa, dimana admin menerima pendaftaran siswa, melakukan penginputan, dan cetak data siswa Organisasi Pencak Silat Persaudaraan Setia Hati Terate Rayon Bekasi.

2. Penginputan Data Pelatih

Prosedur ini dilakukan oleh admin atau sekretaris sebagai bagian dari struktural organisasi yang bertugas mengelola data pelatih, dimana admin menerima pendaftaran pelatih, melakukan penginputan, dan cetak data pelatih Organisasi Pencak Silat Persaudaraan Setia Hati Terate Rayon Bekasi. .

3. Penginputan Data Inventaris

Prosedur ini dilakukan oleh admin atau sekretaris sebagai bagian dari struktural organisasi yang bertugas mengelola data inventaris, dimana sekretaris menginput, dan mencetak data inventaris di ruang lingkup Organisasi Pencak Silat Persaudaraan Setia Hati Terate Rayon Bekasi.

4. Penginputan Pembayaran Kas Siswa

Prosedur ini dilakukan oleh admin atau bendahara sebagai bagian dari struktural organisasi yang bertugas mengelola data pembayaran kas siswa, dimana bendahara menginput, dan mencetak data pembayaran kas siswa di ruang lingkup Organisasi Pencak Silat Persaudaraan Setia Hati Terate Rayon Bekasi.

5. Penginputan Pembayaran Kas Pelatih

Prosedur ini dilakukan oleh admin atau bendahara sebagai bagian dari struktural organisasi yang bertugas mengelola data pembayaran kas pelatih, dimana bendahara menginput, dan mencetak data pembayaran kas pelatih di ruang lingkup Organisasi Pencak Silat Persaudaraan Setia Hati Terate Rayon Bekasi.

\section{Use Case Diagram}

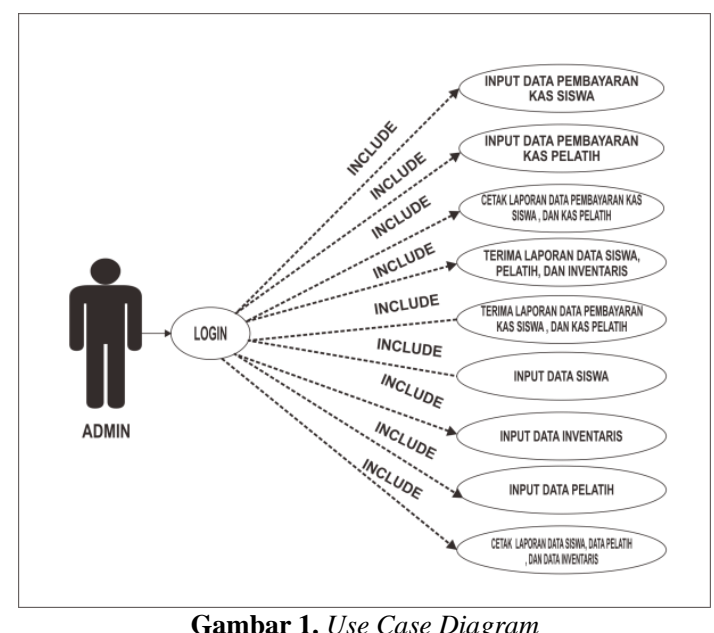

Gambar 1. Use Case Diagram 
Use Case Diagram menampilkan fungsionalitas yang diharapkan dari suatu sistem (Yasin 2013). Pada tampilan diatas merupakan peran dari masing-masing actor. Admin pada aplikasi yang dirancang peneliti merupakan pengurus organisasi yaitu sekretaris dan bendahara

\section{Activity Diagram}

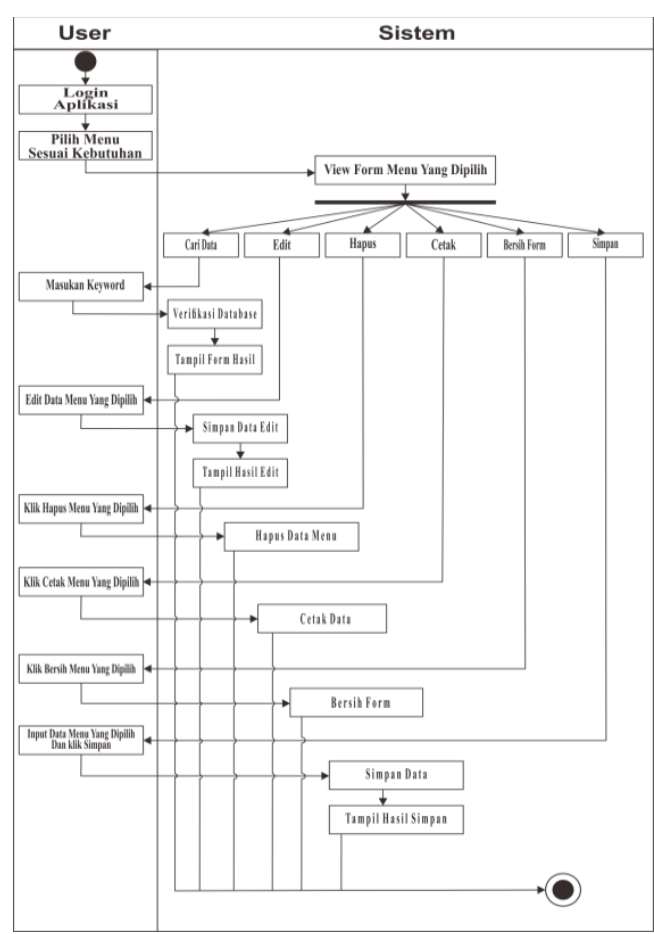

Gambar 2. Activity Diagram

Activity Diagram merupakan suatu permodelan yang menggambarkan aliran dari aktivitas, digunakan untuk mendeskripsikan aktivitas yang dibentuk dalam suatu operasi. Activity diagram dapat juga digunakan untuk menggambarkan suatu kejadian yang ada didalam sistem.(Pakaya, Tapate, and Suleman 2020)

\section{Class Diagram}

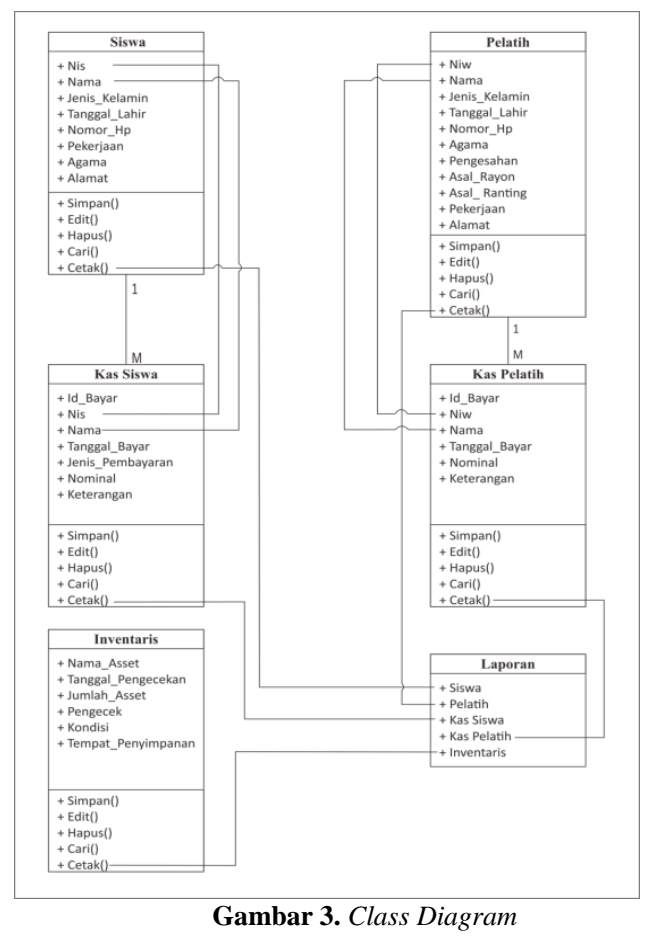


Class Diagram merupakan suatu permodelan yang menggambarkan struktur dari deskripsi class, package dan object beserta hubungan satu sama lain. Pada tampilan diatas merupakan class diagaram yang dibuat peneliti.

\section{Entity Relationship Diagram (ERD)}

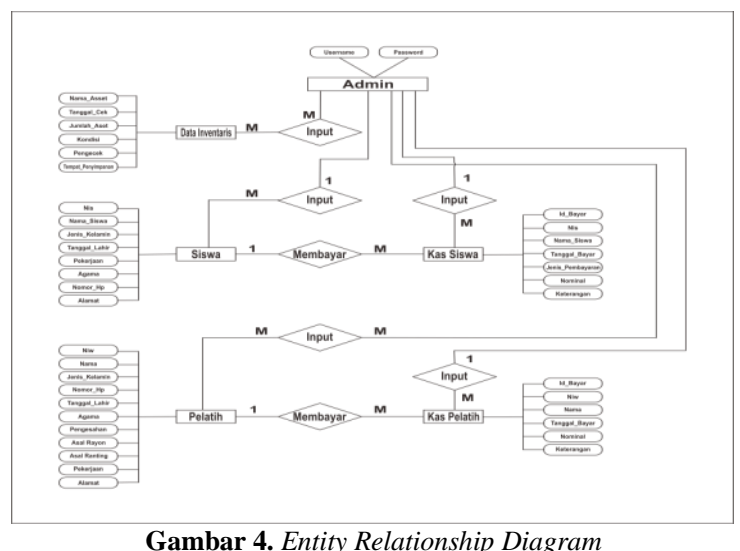

ERD digunakan untuk pemodelan basis data relasional (Salahudin 2018). Pada tampilan diatas merupakan rancangan basis data dari aplikasi yang dibuat peneliti.

\section{Tampilan Layar Data Siswa}

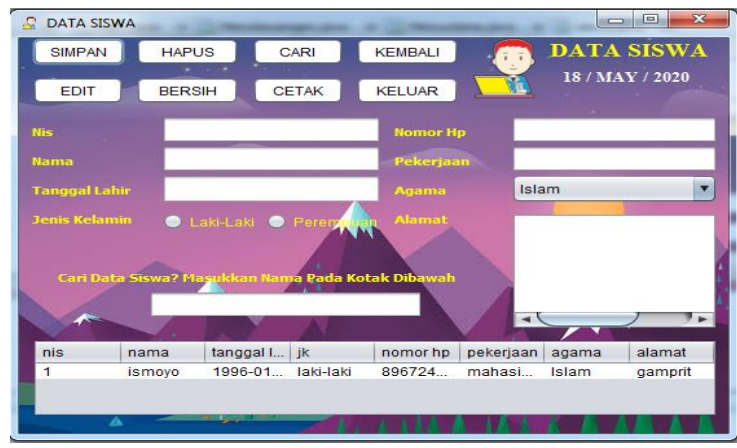

Gambar 5. Tampilan Layar Data Siswa

Pada tampilan diatas merupakan tampilan data siswa. Form ini memiliki beberapa button yang terdiri dari button Simpan untuk menyimpan data siswa, button Edit untuk mengubah data siswa, button Hapus untuk data siswa yang telah tersimpan di dalam database, button Bersih untuk membersihkan form inputan, button Cari untuk mencari data siswa, button Cetak untuk mencetak laporan data siswa, button Kembali untuk kembali ke menu utama, dan button Keluar untuk keluar aplikasi.

\section{Tampilan Layar Pembayaran Kas Siswa}

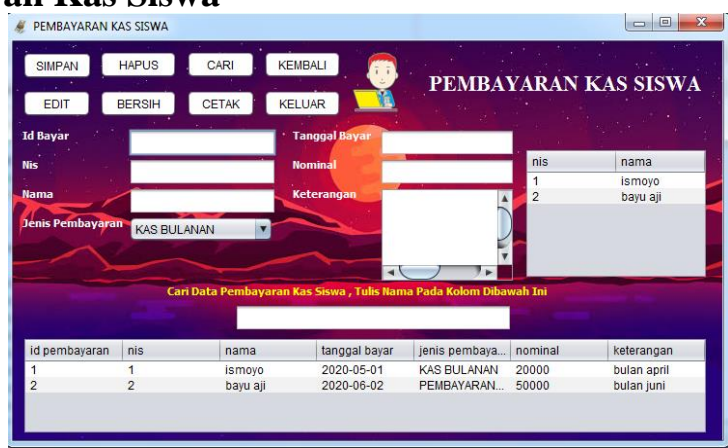

Gambar 6. Tampilan Layar Pembayaran Kas Siswa 
Pada tampilan diatas merupakan tampilan pembayaran kas siswa. Form ini memiliki beberapa button yang terdiri dari button Simpan untuk menyimpan data pembayaran kas siswa, button Edit untuk mengubah data inventaris, button Hapus untuk data pembayaran kas siswa yang telah tersimpan di dalam database, button Bersih untuk membersihkan form inputan, button Cari untuk mencari data pembayaran kas siswa, button Cetak untuk mencetak laporan data pembayaran kas siswa, button Kembali untuk kembali ke menu utama, dan button Keluar untuk keluar aplikasi.

\section{Tampilan Laporan Data Siswa}

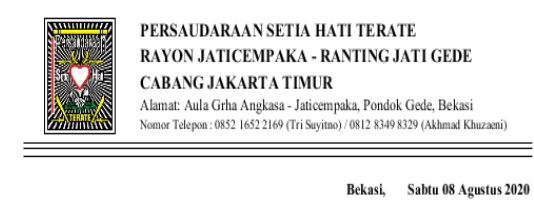

LAPORAN DATA SISWA

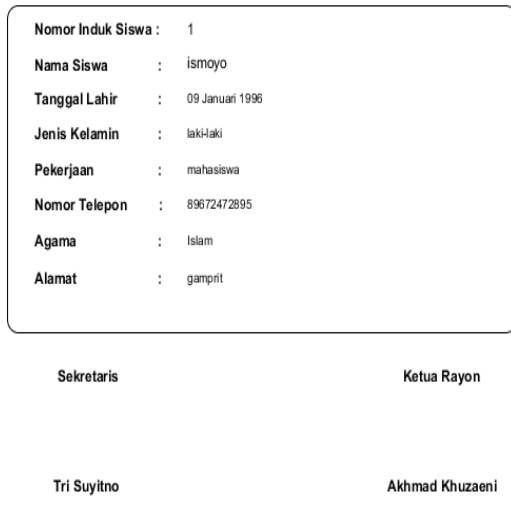

Gambar 7. Tampilan Laporan Data Siswa

Pada tampilan ini berisikan laporan data siswa terdiri dari Nomor Induk Siswa, Nama Siswa, Tanggal Lahir, Jenis Kelamin, Pekerjaan, Nomor Telepon, Agama, dan Alamat. Tampilan ini muncul ketika admin mengklik button cetak.

\section{Tampilan Laporan Pembayaran Kas Siswa}

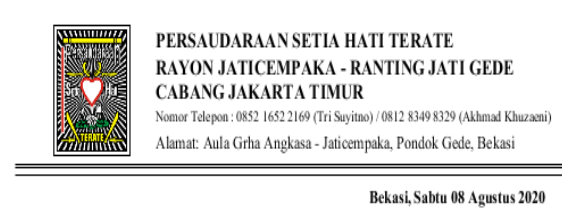

\section{PEMBAYARAN KAS SISWA}

ID PEMBAYARAN : 1
\begin{tabular}{|l|l|}
\hline NIS $: 1$ & JENIS BAYAR: KAS BULANAN \\
\hline NAMA $:$ ismoyo & KETERANGAN: \\
\hline TANGGAL: 01 Juni 2020 & bulan april \\
\hline NOMINAL: 20000 & \\
\hline Bendahara & Ketua Rayon \\
Nurul Cantika & Akhmad Khuzaeni \\
\hline
\end{tabular}

Gambar 8. Tampilan Laporan Pembayaran Kas Siswa 
Pada tampilan ini berisikan laporan pembayaran kas siswa terdiri dari Id Pembayaran, NIS, Nama, Tanggal, Nominal, Jenis Bayar, dan Keterangan. Tampilan ini muncul ketika admin mengklik button cetak.

\section{SIMPULAN}

Dengan adanya aplikasi Organsasi Pencak Silat Persaudaraan Setia Hati Terate Rayon Bekasi, dapat membantu pihak pengurus organisasi dalam hal pengelolaan data-data organisasi, pembuatan laporan, merevisi data, dan melakukan pencarian data dengan cepat dan tepat. Khususnya pendataan data siswa, data pelatih, data inventaris, data pembayaran kas siswa, dan data pembayaran kas pelatih.

\section{DAFTAR PUSTAKA}

Duha, Timotius. 2018. Perilaku Organisasi. Yogyakarta: Deepublish.

Ferdiansyah, Vikri Zulfi. 2017. "Aplikasi Pembelajaran Interaktif Pencak Silat Persaudaraan Setia Hati Terate Berbasis Mobile.” Universitas Muhammadiyah Malang.

Gristyutawati, Anting Dien. 2012. "Persepsi Pelajar Terhadap Pencak Silat Sebagai Warisan Budaya Bangsa Sekota Semarang Tahun 2012." Journal of Physical Education, Sport, Healt and Recreations 4(7): 1957-62.

Ilmiah, Jurnal et al. 2019. “( STUDI KASUS : STIKOM DINAMIKA BANGSA JAMBI ).” 1(4): 276-89.

Nissa, Cendani Khoirun et al. 2020. "PENDIDIKAN ISLAM DAARURRAHMAH BOGOR BERBASIS DESKTOP." 01(02): 259-65.

Pakaya, Roys, Abdul Rahman Tapate, and Salman Suleman. 2020. "PERANCANGAN APLIKASI PENJUALAN HEWAN TERNAK UNTUK QURBAN DAN AQIQAH DENGAN METODE UNIFIED MODELING LANGUAGE ( UML ).” 8(1): 31-40.

Salahudin, Mohamad. 2018. Rekayasa Perangkat Lunak Dan Berorientasi Objek. Bandung: Informatika.

Suyoto, Sandu. 2015. Dasar Metodologi Penelitian. Sleman: Literasi Media Publishing.

Witirani, Nadia Septa. 2017. "Aplikasi Pengelolaan Data Organisasi Mahasiswa." Industrial Research Workshop and national Seminar IX. https://jurnal.polban.ac.id.

Yasin, Verdi. 2013. Rekayasa Perangkat Lunak Berorientasi Objek. Bogor: Mitra Wacana Media. 